\title{
INTERNASIONALISASI DAN REFORMASI PERGURUAN TINGGI: STUDI KASUS PADA LEMBAGA PENDIDIKAN TINGGI MUHAMMADIYAH
}

\author{
Intan Diane Binangkit \\ Dede Iskandar Siregar \\ Program Studi Manajemen Fakultas Ekonomi dan Bisnis Universitas Muhammadiyah Riau \\ E-mail: intandianebinangkit@umri.ac.id
}

\begin{abstract}
Abstrak: Lembaga pendidikan, khususnya pendidikan tinggi, diyakini menjadi ujung tombak pengembangan kualitas sumber daya manusia. Peran strategis yang dimiliki lembaga pendidikan tinggi menjadikan perhatian terhadap peningkatan kualitasnya semakin gencar dilakukan. Artikel ini bertujuan untuk menganalisis bagaimana Perguruan Tinggi Muhammadiyah (PTM) melakukan transformasi lembaga dari skala nasional menuju internasional. Artikel ini dilakukan dengan pendekatan studi kasus dari PTM. Pengumpulan data dilakukan melalui beberapa tahapan diantaranya desk research, interview dan studi dokumen. Adapun analisis dilakukan dengan pattern matching, cross-case synthesis, dan explanation building. Hasil menunjukkan beberapa aspek internasionalisasi PTM. Tata kelola yang baik dalam pencapaian tujuan internasionalisasi sebaiknya didokumentasikan dalam bentuk visi, misi, tujuan, kebijakan mutu serta rencana strategi. Proses internasionalisasi menuntut adanya lembaga khusus yang menangani kerjasama dan kegiatan internasional. Untuk mendukung internasionalisasi, pengembangan SDM dan sistem pengambilan keputusan yang cepat dan tidak kaku menjadi penting untuk diperhatikan.
\end{abstract}

Kata Kunci: tata kelola, internasionalisasi, perguruan tinggi, Muhammadiyah

Abstract: Educational institutions, especially tertiary education, are designed to spearhead the development of the quality of human resources. The strategic role needed by tertiary institutions makes intensive attention to improving its quality. This article discusses how to analyze Muhammadiyah Universities (PTM) to transform institutions from national to international scale. This article is carried out by discussing case studies from PTM. Data collection was carried out through several meetings gathering desk research, interviews and document studies. Analyzes were performed by pattern matching, cross-case synthesis, and explanation building. The results show several aspects of PTM internationalization. Good governance in achieving the objectives of internationalization must be carried out in the form of a vision, mission, goals, quality policy and strategic plan. An internationalization process that demands specialized institutions that require international cooperation and activities. To support internationalization, the development of $H R$ and decision-making systems that are fast and not rigid are important to consider.

Keywords: governance, internationalization, universities, Muhammadiyah

Perkembangan kondisi sosial-ekonomi Indonesia 30 tahun belakangan diiringi meningkatnya partisipasi masyarakat dalam pendidikan tinggi menunjukkan adanya perluasan akses terhadap pendidikan sehingga kualitas sumber daya manusia Indonesia diharapkan dapat semakin maju. Peningkatan partisipasi pendidikan semestinya harus diikuti peningkatan kualitas lulusan dan ini tentu bergantung pada masukan (input), proses, dan penjaminan mutu pendidikan tinggi.
Tingginya partisipasi pendidikan tinggi kenyataannya tidak sepenuhnya berdampak pada pengurangan angka pengangguran nasional. Kementerian Riset, Teknologi dan Pendidikan Tinggi Tahun 2018 mencatat 8,8\% dari total 7 juta pengangguran di Indonesia merupakan mereka para lulusan perguruan tinggi. Ini tentu sangat mengkhawatirkan mengingat persaingan mendapatkan pekerjaan semakin ketat dengan datangnya Revolusi Industri 4.0, dengan sistem produksi yang canggih dan serba otomatis. Kondisi 
tersebut semakin mengkhawatirkan karena pengangguran terdidik tersebut juga harus bersaing dengan pekerja asing (Seftiawan, 2018).

Mahasiswa sebagai salah satu masukan utama pendidikan tinggi bagaimanapun memegang peran besar dalam pencapaian outcome pendidikan. Tahun 2020, Indonesia diprediksi menjadi salah satu negara dengan jumlah mahasiswa terbesar di dunia. Oleh karena itu, perguruan tinggi diharapkan mampu menghasilkan lulusan yang adaptif, tangguh, berintegritas, dan kompeten. Universitas dan mahasiswanya harus berpikiran maju (forward looking) serta mampu menyesuaikan diri terhadap perubahan lingkungan (Oey-Gardiner et al. 2017).

Salah satu hal yang dapat dilakukan untuk mewujudkan sumber daya manusia dan lulusan unggul adalah internasionalisasi perguruan tinggi. Internasionalisasi sendiri menjadi aspek yang menarik perhatian organisasi, baik organisasi bisnis, pemerintah maupun sosial. Secara umum, internasionalisasi diartikan sebagai proses dimana organisasi terlibat dalam lingkungan global (Azuayi, 2017). Alasan internasionalisasi dilakukan diantaranya karena pertimbangan ekonomi, namun perubahan politik, lingkungan sosial dan budaya. Dorongan lain juga muncul akibat tekanan pasar domestik yang tidak bisa memenuhi kebutuhan organisasi dan adanya peluang yang ditawarkan pasar global (Hill, 2012) sehingga perubahan paradigma pasar domestik ke global penting dilakukan untuk memastikan keberlanjutan organisasi (Morrison, 2011).

Persyarikatan Muhammadiyah yang menaungi 166 institusi pendidikan tinggi di Indonesia menyadari pentingnya internasionalisasi lembaga pendidikan. Upaya tersebut dilakukan untuk memastikan setiap lulusan dari Perguruan Tinggi Muhammadiyah (PTM) memiliki kemampuan menghadapi globalisasi dan mempromosikan nilai-nilai kemanusiaan universal. Sebagai lembaga yang membawa konsep berkemajuan, PTM harus bisa maju ke pentas global dengan mengirimkan mahasiswa dan dosen ke berbagai negara lain dalam program pertukaran mahasiswa, dosen dan program pendidikan. Perguruan tinggi yang memiliki daya saing global harus mampu mendorong dosen melakukan publikasi internasional dan menggunakan materi pembelajaran yang diadaptasi dari luar. Dari segi manajemen, perguruan tinggi yang memiliki citra di lingkungan internasional menerapkan sistem tata kelola berstandar internasional, seperti akreditasi internasional.

Banyak penelitian terkait internasionalisasi organisasi namun umumnya berkonsentrasi pada faktor penghambat yang terdiri dari faktor budaya, politik (Karakaya and Michael, 1991; Beamish, 1990) dan persaingan (Yang et al., 2006; Karakaya and Michael, 1991) sebagai fokus penyelidikan. Disamping itu, penelitian tersebut juga kebanyakan dilakukan di perusahaan multinasional berorientasi bisnis. Penelitian yang membahas internasionalisasi perguruan tinggi pernah dilakukan Fuadi (2017). Dalam studinya tersebut beliau menekankan penguatan pada aspek manajemen, kurikulum, banchmarking, dan promosi sebagai prasyarat internasionalisasi. Bagaimanapun hingga sekarang belum ditemukan penelitian yang khusus mengkaji bagaimana lembaga pendidikan tinggi khususnya PTM melakukan internasionalisasi. Penelitian dibidang tentu penting karena internasionalisasi memungkinkan dilakukan apabila organisasi memiliki kerangka strategi yang jelas dan terarah. Oleh karnea itu, pertanyaan penelitian yang diajukan disini adalah bagaimana tata kelola internasionalisasi PTM, dan bagaimana reformasi institusi dari skala nasional ke internasional?

\section{METODE}

Penelitian ini bersifat eksploratif yang menganalisis bagaimana perguruan tinggi melakukan internasionalisasi. Strategi yang dugunakan untuk menjawab pertanyaan penelitian mengacu pada kerangka penelitian kualitatif berdasarkan pendekatan studi kasus (Yin, 2013). Sampel yang digunakan adalah PTM yang dipilih karena beberapa alasan. Pertama, sebagai sebuah lembaga penyedia layanan pendidikan di tingkat universitas, PTM adalah milik organisasi keagamaan dimana dalam pengelolaanya dilakukan dengan mengacu pada prinsip dan kaidah Islam. Kedua, setiap mahasiswa dan pegawai di PTM dibekali dengan kegiatan Darul Arqam Dasar, pelatihan kepemimpinan Islam, sehingga mereka memiliki pemahaman yang mendalam tentang nilai-nilai kemanusiaan berdasarkan 
ajaran Islam yang harus diterapkan disetiap aspek kehidupan. Terakhir, selain melaksanakan Tri Dharma Perguruan Tinggi PTM memiliki aspek pembeda dalam kurikulumnya yaitu amar ma'ruf nahi munkar, mengajak atau menganjurkan kepada kebaikan dan mencegah dari tindakan keburukan. Karakteristik tersebut bagaimanapun membuat studi ini memberikan kontribusi yang cukup signifikan dalam memahami konsep internasionalisasi berdasarkan sudut pandang lembaga pendidikan tinggi yang berbeda.

Proses pengumpulan dilakukan melalui beberapa metode yaitu desk research, interview dan studi dokumen. Desk research dilakukan dengan menggali informasi yang tersedia di publik, baik melalui internet maupun laporan perusahaan. Semistructured interview dilakukan bersama rektor, pengelola Kantor Urusan Internasional (KUI), dan pimpinan Majelis Pendidikan Tinggi, Penelitian dan Pengembangan (Diktilitbang) Pimpinan Pusat Muhammadiyah. Pemilihan responden tersebut sebagai sumber data dianggap tepat karena mereka merupakan orang yang langsung terlibat dalam perencanaan strategi internasionalisasi di lembaganya. Metode pengumpulan data terakhir adalah analisis dokumen, dimana ini bertujuan untuk meningkatkan reliabilitas penelitian melalui triangulasi sumber (Eisenhardt, 1989; Yin, 2013).

Analisis data dilakukan melalui pattern matching, cross case synthesis, dan explanation building (Eisenhardt, 1989; Miles et al., 2014). Analisis pertama dilakukan dengan memberikan deskripsi tentang proses internasionalisasi di lembaga (Creswell, 2012). Analisis kedua (cross-case synthesis) dilakukan dengan membandingkan antara teori dan temuan studi kasus di lapangan sehingga generalisasi dapat dilakukan (Miles et al., 2013; Voss et al., 2002). Adapun explanation building bertujuan membantu peneliti mengidentifikasi argumen yang mendasari munculnya pola-pola yang ditemukan berdasarkan temuan studi kasus di lapangan (Eisenhardt and Graebner, 2007).

\section{HASIL DAN PEMBAHASAN}

\section{$R Q$ 1: Bagaimana tata kelola proses internasionalisasi PTM dalam wujud self- governance?}

Salah satu hal yang diperlukan dalam proses internasionalisasi adalah sebuah manajemen tata kelola internasionalisasi. Hasil wawancara dengan responden ditemukan beberapa poin tentang aspek tata kelola internasionalisasi PTM yang akan dijabarkan berikut ini:

\section{Internasionalisasi Visi, Misi, Tujuan, Rencana Strategi, dan Operasional serta Kurikulum}

Dalam mencapai tujuan internasionalisasi, secara deklaratif perguruan tinggi menuangkan cita-citanya dalam bentuk visi dan misi serta tujuan. Visi merupakan rangkaian kalimat yang menyatakan cita-cita dan impian organisasi atau lembaga di masa depan (Wibisono, 2006). Secara umum, internasionalisasi perguruan tinggi memiliki visi yakni menciptakan lulusan yang cerdas dan memiliki daya saing global. Untuk menuju perwujudan tersebut, diperlukan strategi terencana, terarah dan sistematik yang kemudian dituang dalam rencana strategi dan rencana operasional universitas. Oleh karena itu, tata kelola yang baik dalam pencapaian tujuan internasionalisasi sebaiknya didokumentasikan dalam bentuk visi, misi, tujuan, kebijakan mutu serta renstra. Sebagai contoh visi yang memuat misi internasionalisasi adalah visi Universitas Ahmad Dahlan (UAD), "Menjadi perguruan tinggi yang diakui secara internasional, dan dijiwai nilai-nilai Islam". Pernyataan tersebut menunjukkan orientasi lembaga dalam menunjukkan dirinya di mata internasional dan secara deklaratif lembaga tersebut telah menuangkan cita-citanya sebagai lembaga perguruan tinggi internasional dalam misi dan rencana strategisnya.

Berkenaan dengan penentuan strategi internasionalisasi, studi ini mengkonfirmasi bahwa PTM telah membagi strategi menjadi dua dimensi yakni strategi internal dan strategi eksternal. Strategi internal adalah strategi yang dirancang kelembagaan yang fokus pada pengembangan internal perguruan tinggi (aspek keorganisasian). Adapun strategi eksternal adalah merupakan program aksi internasionalisasi yang dicantumkan dalam rencana yang matang dan berjangka panjang 
setelah perumusan visi-misi dan/atau Renstra Internasionalisasi perguruan tinggi.

Selain deklarasi melalui dokumen, pimpinan perguruan tinggi juga berusaha mendorong kesadaran dan tanggung jawab semua departemen yang ada untuk mewujudkan tercapainya visi dan misi. Koordinasi, mutual understanding antara internal dan eksternal akan perwujudan visi misi universitas menjadi modal utama pelaksananaan internasional.

\section{Lembaga-lembaga yang berperan dalam Internasionalisasi PTM}

Agar tujuan internasionalisasi tercapai, diperlukan suatu lembaga khusus yang menangani kerjasama internasional dan mengelola program-program atau kegiatan internasional. Unit kerja yang menangani kegiatan internasional di PTM saat ini adalah Kantor Urusan Internasional (KUI). Dalam pelaksanaannya, KUI tidak bekerja sendiri. Keterlibatan pimpinan prodi, fakultas dan semua bidang di lingkungan Rektorat menjadi awal dari kegiatan perencanaan program internasionalisasi.

Hasil hasil wawancara yang dilakukan dengan responden dikonfirmasi bahwa salah satu asosiasi dibawah Majelis Diktilitbang PP Muhammadiyah yang mendukung tujuan internasionalisasi PTM adalah Asosiasi KUI-PTM. Semua pimpinan KUI di seluruh PTM se-Indonesia tergabung disini. ASKUI-PTM berfungsi sebagai jembatan antara perguruan tinggi dengan pihak luar yang direkomendasikan Majelis Diktilitbang PP Muhammadiyah. Dalam ASKUI-PTM, dilakukan pembinaan oleh PTM yang sudah lebih maju dan PTM yang masih berkembang. PTM yang masih berkembang akan mendapatkan informasi dan pendampingan melakukan kerjasama internasional dari PTM yang sudah maju. Dengan demikian, seluruh PTM diharapkan bergerak maju bersama-sama dalam pencapaian tujuan Internasionalisasi Gerakan Muhammadiyah di lingkungan global.

\section{Prosedur Pelaksanaan Kerjasama Internasional}

Dalam pelaksanaan kegiatan kerjasama, PTM memperhatikan dengan detail setiap tahapan dan prosedur yang dibuat. Dimulai dari penjajakan kerjasama dan analisis calon mitra. Penjajakan kerjasama adalah tahapan awal mekanisme kerjasama yang dilakukan unit kerja di masingmasing PTM (Fakultas, Lembaga, PPs, dan unit kerja lain) atau KUI. Ini dilaksankan setelah mendapatkan izin dari unit kerja dan KUI. Tahapan selanjutnya adalah pengkajian dan pengesahan kerjasama dimana disini PTM menindaklanjuti setiap kerjasama yang dituangkan dalam rancangan perjanjian kerjasama yang ada.

Tahapan selanjutnya adalah tahapan pelaksanaan, monitoring, evaluasi, pengembangan program dan perpanjangan kerjasama ketika waktu berakhir, sesuai kesepakatan bersama. Rencana kerjasama yang dilakukan perorangan, kelompok atau unit kerja di lingkungan PTM harus dipayungkan terlebih dahulu melalui MoU. Naskah Perjanjian kerjasama perlu dituangkan dalam bentuk Nota Kesepakatan (MoU dan MoA). Kedua dokumen ini dibuat oleh pengusul dan mitra kerja untuk emudian disepakati masing-masing pihak.

\section{Monitoring dan Evaluasi Kerjasama}

Semua aktifitas kerjasama perguruan tinggi dalam tata kelola internasionalisasi dilaksanakan sebagai bentuk perwujudan penandatanganan MoU/MoA. Ketika dalam suatu PTM pelaksanaannya tidak berjalan, maka dilakukan evaluasi. Hal ini dilakukan karena syarat penilaian kualitas perguruan tinggi adalah persentase implementasi kerjasama MoU/MoA. Tujuan monev kerjasama adalah untuk memantau semua kegiatan kerjasama ditingkat nasional maupun internasional memperoleh berbagai masukan guna meningkatkan kualitas serta memperoleh berbagai informasi penting khususnya bagi Badan Penjaminan Mutu, Lembaga Pengawasan dan Pengendalian Mutu (LPPM) dan Pimpinan universitas untuk pengambilan keputusan atau menentukan kebijakan.

Dalam hal monev kerjasama internasional, beberapa PTM telah menyusun instrumen survey kepuasan mitra kerjasama seperti yang dilakukan oleh Universitas Muhammadiyah Yogyakarta. Lembar jawaban ini disediakan secara online, diisi mitra dan pihak yang terkait dalam pelaksanaan program internasional. Beberapa satisfaction survey yang dikembangkan diantaranya adalah Partnership Satisfaction Survey-International Cooperation, Survei Kepuasan Kerjasama Domestik, 
Student Mobility Satisfaction Survey, Staff and Visiting Fellow Satisfaction Survey.

Selanjutnya, objek monev tidak hanya focus pada kegiatan kerjasama, namun lembaga perguruan tinggi yang menaungi kerjasama tersebut juga dievaluasi secara periodik melalui instrumen penilaian yang telah disusun lembaga mutu tingkat di fakultas/universitas. Dari beberapa rubrik standar mutu yang ada, terdapat dua poin yang dievaluasi yakni Standar Kerjasama dan Standar Internasionalisasi. Dalam Standar Kerjasama, dijelaskan mengenai prosedur mutu kerjasama, monev kegiatan kerjasama, publikasi domumentasi dari kegiatan kerjasama, bidang kerjasama yang lengkap terkait pelakanaan Tri Dharma Dharma. Sedangkan dalam poin Standar Internationalisasi, membahas aspek pengajaran, proporsi mahasiswa international (inbound maupun outbond), pelaksanaan program internationalisasi,dan instrumen penyelenggaraan program pendidikan kelas internasional. Kegiatan menotoring dan evaluasi tersebut penting dan dilakukan secara rutin demi keberhasilan kerjasama. Berhubungan dengan ini berikut pernyataan Kepala salah satu KUI:

"Monitoring dan Evaluasi kerjasama menjadi penting karena keberhasilan sebuah kerjasama dapat dilihat dari kesesuaian antara perencanaan dengan pelaksanaan dan hasil yang dicapai sesuai kesepakatan yang dibangun. Pada dasarnya monitoring dan evaluasi dilakukan dengan cara memantau hasil yang dicapai dan jika terdapat masalah maka harus segera dicarikan solusinya sehingga program dapat berjalan dengan semestinya".

Untuk mendukung implementasi tata kelola perguruan tinggi, PTM menerapkan beberapa pendekatan sebagai berikut:

\section{Pengembangan staf akademik dan non- akademik}

Perguruan tinggi perlu memiliki support dari sumber daya manusianya demi tercapainya tujuan internasionalisasi. Oleh karena itu, pengembangan staf akademik dan non-akademik perlu diperhatikan. Dengan mengadakan kerjasama domestik maupun internasional dalam bidang pendidikan, perguruan tinggi dapat terbilang sukses memberikan kemudahan bagi para staf akademik maupun non-akademik yang untuk melanjutkan pendidikan. Perguruan tinggi juga perlu memberikan proporsi pelatihan yang cukup dan adil bagi para staf yang terlibat dalam kegiatan internasionalisasi. Pelatihan dapat berupa penguatan kemempuan bahasa asing dan ketrampilan komunikasi interpersonal.

Dalam hal ini, hasil wawancara responden menunjukkan bahwa PTM telah secara rutin memberikan berbagai pengembangan staf yang dilakukan melalui kegiatan workshop dan seminar. Namun demikain, distribusi pengembangan antara staf akademik dan nonakademik masih belum merata. Hal ini disebabkan oleh beberapa staf akademik dan non-akademik belum memiliki minat untuk mengikuti kegiatan-kegiatan yang berhubungan dengan internasionalisasi. Oleh karena itu, diperlukan motivasi pimpinan di masing-masing unit kerja untuk mendorong semua lini turut serta dalam pencapaian tujuan perguruan tinggi.

\section{Mempersiapkan visi yang konkret dan rencana jangka menengah}

Visi sebuah perguruan tinggi adalah gambaran masa depan yang ingin dicapai dan ini perlu dirumuskan dengan konkret beserta dengan rencana jangka menengah yang secara logis bisa dijangkau. Di PTM, penyusunan/perubahan visi melibatkan banyak stakeholder internal dan eksternal. Bagi PTM yang visi misi-nya belum mencerminkan orientasi internasionasional, maka didorong untuk melakukan benchmarking, sebagaimana dengan yang dilakukan oleh PTM lain. Benchmarking di dalam negeri juga diupayakan dan ini sering melibatkan Majelis Diktilitbang dan PP Muhammadiyah.

\section{Mempercepat proses pengambilan keputusan}

Salah satu peran pemimpin adalah sebagai pengambil keputusan. Sebagai perguruan tinggi swasta, PTM membutuhkan pemimpin yang cekatan dalam mengambil hal ini agar kinerja internasionalisasi tidak kalah dari perguruan tinggi lain. Proses internasionalisasi adalah proses dimana perguruan tinggi secara bertahap meningkatkan keterlibatannya di ranah internasional. Internasionalisasi dapat mengalami kegagalan apabila pimpinan lambat dalam mengambil keputusan terkait 
dengan perencanaan, pengorganisasian, pengawasan dan pengarahan seluruh kegiatan yang mendukung proses internasionalisasi.

Selain kebutuhan pemimpin yang sadar akan pentingnya internasionalisasi, aspek lain yang harus dibenahi adalah birokrasi. Dalam organisasi, aspek ini harus diselenggarakan dengan ringkas sehingga efisiensi dan atau efektivitas bisa dipenuhi. Suatu perguruan tinggi dapat dikatakan memiliki birokrasi efisien apabila pihak yang terlibat dalam sistim administrasi memiliki kemampuan mengoptimalkan pemanfaatan segala sumber daya yang tersedia dalam pelaksanaan fungsi dan tugasnya. Sedangkan birokrasi yang efektif merupakan proses yang berfokus pada pencapaian sasaran, baik dari segi waktu maupun dana yang dialokasikan.

\section{Mengikutsertakan stakeholder eksternal dalam pengambilan keputusan}

Keberadaan dan citra suatu perguruan tinggi tidak semata-mata bergantung pada pemerintah, namun penilaian stakeholder eksternal juga menjadi aspek yang menentukan. Peran stakeholder ini sangat penting karena posisi mereka dapat menentukan keberlanjutan perguruan tinggi. Lingkup stakeholder ini mencakup dengan mahasiswa (aktual maupun potensial), badan akreditasi, orang tua/wali, pesaing, pemasok, lembaga swasta hingga masyarakat setempat dan media. Mereka tersebut merupakan komponen penting dalam peningkatan kualitas perguruan tinggi. Oleh karena itu, perlu ada rancangan model pemetaan dan posisi masing-masing stakeholder di setiap perguruan tinggi.

Studi ini menunjukkan bahwa semua PTM telah melakukan pemetaan peran dan posisi masing-masing stakeholder yang ada. Selain melakukan pemetaan, termasuk peran dan signifikansi stakeholder, PTM juga melakukan riset tentang "Interest vs Power Analysis of Stakeholder" secara rutin, dimana ini bertujuan untuk mengetahui besarnya tingkat pengaruh dan kepentingan mereka terhadap lembaga.

\section{RQ2: Bagaimana reformasi institusi PTM dari skala nasional ke internasional?}

Reformasi perguruan tinggi dari skala nasional menuju global atau internasional melibatkan banyak faktor penting. Faktorfaktor tersebut diantaranya dijelaskan berikut ini.

\section{Standar Kinerja Perguruan Tinggi}

Standar kinerja perguruan tinggi khususnya di Indonesia berangkat dari standar nasional Dari hasil wawancara responden, PTM memiliki tekad kuat untuk menjadikan kampusnya berakreditasi internasional. Majelis Diktilitbang PP Muhammadiyah senantiasa mengadakan workshop internasionalisasi sebagai upaya sosialisasi kepada para pimpinan dan pemangku kebijakan di masing-masing PTM. Bahkan dalam setiap seminar yang diadakan Majelis Diktilitbang, tema internasionalisasi selalu digaungkan dengan harapan semangat membawa nama Muhammadiyah di tingkat global kepada seluruh PTM dapat tercipta. Para pimpinan PTM menyikapi hal tersebut dengan positif dan optimis dibuktikan dengan dorongan terhadap pengadaan exchange program (inbound atau outbond), kerjasama internasional bidang penelitian dan penerbitan artikel ilmiah Internasional bagi para dosen dan mahasiswa. Standar pengabdian kepada masyarakat juga telah mengarah ke ranah internasional dengan mendatangkan mahasiswa ke dalam negeri melalui kegiatan community service.

\section{Dampak Benchmarking}

Benchmarking bukan hanya sekedar memberi tanda. Pendekatan ini juga dimaksudkan untuk mengidentifikasi praktik terbaik yang dapat diadopsi dan diimplementasikan organisasi meningkatkan kinerja perusahaan (Freytag and Hollensen 2001). Dalam dunia pendidikan, benchmarking bertujuan untuk mengatur dan meningkatkan kualitas dan standar akademik dengan membandingkan proses yang berjalan dengan sistem yang telah dirancang. Sifat alamiah perguruan tinggi addalah knowledge-sharing yang direalisasikan melalui pertemuanpertemuan ilmiah, seminar, publikasi, mailinglist, dan kegiatan lainnya (Ruswidiono, 2011). Benchmarking dapat dilakukan melalui pendekatan internal dan external. Pendekatan pertama dilakukan dalam dilingkungan prodi, dan fakultas. Adapun pendekatan yang kedua, 
external benchmarking, dilakukan terhadap lembaga/instansi lain (lintas lembaga) baik di dalam negeri maupun di luar negeri. Pelaksanaan benchmarking biasanya meliputi beberapa tahapan. Dimulai dari menentukan apa yang akan dibenchmark; menentukan apa yang akan diukur; menentukan kepada siapa akan dilakukan benchmark; pengumpulan data/ kunjungan tim yang dibentuk; analisis data; dan merumuskan tujuan dan rencana tindakan (Ruswidiono, 2011).

Bagaimanapun juga, dari data dan hasil wawancara responden, studi ini menemukan bahwa PP Muhammadiyah melalui Majelis Dikti Litbang mengarahkan setiap pimpinan PTM melakukan benchmarking rutin baik di internal maupun eksternal. Sebelum melakukan benchmarking ke negara lain, PTM terlebih dahulu melakukan benchmarking di beberapa perguruan tinggi dalam negeri yang sudah memiliki nama di level internasional, seperti Universitas Gadjah Mada.

\section{Teknik Marketing Perguruan Tinggi}

Teknik pemasaran yang diterapkan perguruan tinggi dalam rangka mempromosikan program internasionalnya menjadi salah satu poin penting dalam proses reformasi institusi. Sebagai unsur penunjang internasionalisasi, peningkatan jumlah mahasiswa asing menjadi target utama. Untuk menarik mahasiswa asing, PTM melakukan hal-hal mendasar, dimulai dari menyediakan kemudahan akses informasi, melakukan kunjungan ke kampus luar negeri terutama ke negara ASEAN, menyelenggarakan pameran pendidikan di beberapa kedutaan luar negeri, serta penyediaan beasiswa penuh bagi mahasiswa luar negeri.

\section{KESIMPULAN}

Hasil studi ini bagaimanapun mengkonfirmasi beberapa poin penting terkait tata kelola PTM dalam transformasi skala nasional menuju internasional. Pertama, proses internasionalisasi semestinya dilakukan dengan teliti dan setiap tahapan perlu didokumentasikan dalam bentuk visi, misi, tujuan, kebijakan mutu serta rencana strategis lembaga. Kedua, internasionalisasi dilakukan dengan fokus dan universitas perlu membentuk lembaga khusus yang menangani kerjasama dan atau kegiatan internasional termasuk pengelolaan program internasional. Ketiga, dalam pelaksanaan kerjasama, tahapan dan prosedur kerja sama menjadi aspek yang perlu mendapat perhatian khusus karena tujuan kerja sama bisa dicapai dengan adanya kejelasan pada aspek tersebut. Keempat, monitoring dan evaluasi kerjasama harus dilakukan secara rutin demi keberhasilan kerjasama. Disampng itu, internasionalisasi memungkinkan dicapai ketika lembaga memiliki standar kinerja, benchmarking yang sistem pemasaran yang mendukung.

\section{SARAN}

Beberapa saran yang mungkin bisa menjadi masukan bagi pengelola perguruan tinggi dan pemangku kebijakan dalam melakukan internasionalisasi diantaranya yang pertama adalah mempersiapkan sumber daya manusia, baik akademik dan non akademik, yang siap dalam aktivitas dan iklim internasional. Disini juga diperlukan kejelasan visi misi yang mendukung dan mendorong pelaksanaan internasionalisasi. Kedua, program internasional harus sejalan dengan visi, misi, ide dan gagasan universitas. Transparansi dalam kegiatan benchmarking juga harus dipenuhi sehingga luaran dokumen laporan dapat dijadikan sebagai pedoman dalam melakukan benchmarking.

\section{Acknowledgement}

Penelitian ini dibiayai Majelis Pendidikan Tinggi PP Muhammadiyah melalui skema RisetMu dengan nomor kontrak 0984.069/I.3/D/2019.

\section{DAFTAR RUJUKAN}

Azuayi, Robert. 2017. "Internationalization Strategies for Global Companies: A Case Study of Arla Foods, Denmark." Journal of Accounting \& Marketing 05(04).

Beamish, PW. 1990. "The Internationalization Process for Smaller Ontario Firms: A Research Agenda, Research in Global Strategic Management." International Business Research for the Twenty First Century.

Creswell, John W. 2012. Qualitative Inquiry \& Research Design: Choosing among Five Approaches. 4th ed. Thousand Oaks, CA: Sage. 
Eisenhardt, K. M. 1989. "Building Theories from Case Study Research." The Academy of Management Review 14(4):532-520.

Eisenhardt, Kathleen M. and Mellissa E. Graebner. 2007. "Theory Building from Cases: Opportunities and Challenges Diverse." Academy of Management Review 50(1):25-32.

Freytag, Per V. and Svend Hollensen. 2001. "The Process of Benchmarking, Benchlearning and Benchaction." The TQM Magazine 13(1):25-34.

Fuadi, Djalal. 2017. "Internasionalisasi Perguruan Tinggi: Studi Kasus Pada Perguruan Tinggi Islam Di Yogyakarta." in The Progressive and Fun Education Seminar.

Hill CWL. 2012. International Business in the Global Market Place. 9th ed. McGrawHill Higher Education.

Karakaya, Fahri and Stahl Michael J. 1991. Entry Barriers and Market Entry Decisins: A Guide for Marketing Executives. Greenwood Press.

Miles, Matthew B., A. Michael Huberman, and Saldana Johnny. 2013. Qualitative Data Analysis. Third. Sage Publication Inc.

Miles, Matthew B., A. Michael Huberman, and Saldaña Johnny. 2014. Qualitative Data Analysis: A Methods Sourcebook. 3rd ed. SAGE Publication.

Morrison, Elizabeth W. 2011. "Employee Voice Behavior: Integration and Directions for Future Research." Academy of Management Annals 5(1):373-412.

Oey-Gardiner, Mayling, Susanto Imam Rahayu, Muhammad Amin Abdullah, Sofian Effendi, Yudi Darma, Teguh Dartanto, and Cyti Daniela Aruan. 2017. ERA DISRUPSI: Peluang Dan Tantangan Pendidikan Tinggi Indonesia. Jakarta: Akademi IImu Pengetahuan Indonesia.

Ruswidiono, R. W. 2011. Peningkatan Mutu Dan Benchmarking Perguruan Tinggi. Jakarta: Media Bisnis.

Seftiawan, Dhita. 2018. "630.000 Orang
Sarjana Masih Menganggur." March.

Voss, Chris, Nikos Tsikriktsii, and Mark Frohlich. 2002. "Case Research in Operations Management." International Journal of Operations and Production Management 22(2):195-219.

Wibisono, Dermawan. 2006. Manajemen Kinerja. Jakarta: Erlangga.

Yang, Yoo S., Robert P. Leone, and Dana L. Alden. 2006. "A Market Expansion Ability Approach to Identify Potential Exporters." Journal of Marketing 56(1):84.

Yin, Robert K. 2013. Case Study Research and Applications: Design and Methods. SAGE Publication. 